\title{
10. Performing Arts and the Promotion of Health
}

\author{
Alessandro Pontremoli \\ doi.org/10.3280/oa-637-10
}

\section{Health, No Matter What!}

The concept of health, like every other concept, has a cultural origin and undergoes epistemic changes with time. Together with the discourses it produces, it is strongly influenced by the zeitgeist. Today more than ever before:

the preoccupation with what, for lack of a better word, we call "health", has invaded our everyday life. One could almost consider it an activity in itself and for itself, separate from other preoccupations (Benasayag, 2008, p. 9).

The phenomenon of «health at all costs» (ibid.), which generates compulsive behaviours imposed by an obsession with healthy living, stems from a vision of the living person as an aggregate which is required to work as a machine, different from inanimate machines only from a quantitative point of view (Benasayag, 2018, pp. 56-57).

Gripped by their fear of death, parents are possessed by a fierce desire to defend their children in order to prepare them to face a competitive and economistic society, where the individual is considered like a private firm, and is valued and judged in quantitative terms. In a society where the sum of competencies is what really counts, old age and ill health must be concealed in order to parade individuals always equipped with the plasticity required to adapt to change and to the advancements of technology. The same applies to people affected by disabilities: only the thriving, highly driven ones are tolerated. In order not to cause uneasiness because of their fragility - a fragility common to us all but "obscenely" displayed by them - disabled people are required, as old people are, to appear as «asexual angels, devoid of desire, alien to wickedness; to walk around displaying their gratitude for the fact of being tolerated» (Benasayag, 2018, p. 22).

The recent pandemic emergency has dramatically highlighted this situation: on the one hand, the lockdown, with the closure of schools and of every educational agency, has de facto achieved the biopolitical containment of the potential of the new generations; on the other hand, it has made the 
marginalisation of the elderly and the disabled, more exposed to the risk of contagion, painfully clear. The obsession of contemporary society with the removal of death and illness has shown its sinister and deceitful face in this terrible circumstance of collective and universal trauma. As Judith Butler writes:

To seek a form of human action capable of overcoming death is itself impossible and dangerous, taking us further away from a sense of the precariousness of life. In this perspective, the body imposes a principle of humility and a sense of the necessary limit of all human action (Butler, 2015, p. 47).

In this context it is clear that health is not considered by the powers that be as an inalienable right, because it is too dependent on the inequalities created by capitalist society and by the practice of extreme liberalism. The unequal demographic distribution of precariousness brings to the surface an extreme differential exposure to mortality, a condition peculiar to people affected by fragility and subordination.

What the establishment is doing in the present, which is well described by Giorgio Agamben, is the deconstruction of life. In order to define itself, the state power must be founded on bare life, preserved and protected if it is subjected to the right to life and death of a sovereign and of the law (Agamben, 1995 and 2011, p. 90), it must therefore separate the bare life, the mere abstract precondition of human life, from the forms-of-life for which life is compromised (Agamben, 2011, p. 89). And it is on this nudity that the power apparatus of medicine perpetuates its process of prescriptive subjectivisation, which originates the concept of healthy man: «the preoccupation with a "healthy life" serves as a springboard for the affirmation of the social norm over laws and codices» (Benasayag, 2008, p. 12).

\section{Action, Health and Performance}

The utilitarian grid of functions is not enough to understand our bodies, our lives, our societies: life experiences imply complex mechanisms not susceptible to modelling. For living beings, the world is experience and their acts are always caused in a horizon of meaning and are carriers of meaning (Benasayag, 2018, p. 76).

Miguel Benasayag states that the body is constantly in action (Noë, 2004; Berthoz, 2009), independent of any centre of control and it «develops through movements; a knowing body is in full action» (Benasayag, 2008, p. 102). For the well-being and health of people it is therefore essential to 
strengthen and develop their "power to act". Along the same lines, Paul Ricoeur defined freedom not in relation to moral laws but to the body, intended as a unified and indissoluble mixture of own subject and own body. A body intended as flesh, immersed in the chiasm of the visible and of the sensitive in a situation of reversibility, is the condition of the possibility of freedom.

Maurice Merleau-Ponty pointed out that:

the thickness of the body, far from rivalling that of the world, is [...] on the contrary the sole means I have to go unto the heart of the things, by making myself a world and by making them flesh ([1964] 1968, p. 135).

Human actions are therefore an immanent experience, rooted in life. The creative action, capable of «impressing the character of being on change», manifests and reveals itself not in contemplative forms, but rather in the experiential forms of art, the art that Nietzsche identified with the will to power, and Ricoeur matched, thanks to the similar concept of puissance d'agir, or power to act, with human freedom (Ricoeur, [2004] 2005, pp. 8993 and 134-149; see also Piras, 2007). Social theatre and performance are based on what Ricoeur, utilising a concept defined by Arthur Danto, calls the «basic actions», those actions we can carry out directly with our bodies without the mediation of other actions (Danto, 1965). Voluntary movements, therefore, performed immediately, directly dependent on the power of the subject. These movements, constituting a knowledge without representation, are, according to Ricoeur, a way to access reality as power, they are «the conatus, or the power of being of all things» (Ricoeur, [1990] 1992, p. 316), practical capability to start a course of action in the world (Piras, 2007, p. 120). Similarly, Agamben affirms that:

a political life, that is oriented towards the idea of happiness and cohesive in a form-of-life, can be thought of only starting from the emancipation from this split, from the irrevocable departure from every sovereignty. [He asks himself] is it possible, today, is there today anything like a form-oflife that is to say a life for which, in its own life, life itself is implicated, a life of the power? (Agamben, 2011, p. 92).

He replies that thought is the constitutive connection of the form-of-life, thought intended as experience «that has the potential character of human life and intelligence as its object(s)» (ibid., p. 93). The experience of thought configures itself always as the experience of a common power, that is, as an identification «without residue» between community and power.

This plural human action therefore has an eminently bodily character and, as 
Butler points out:

the body or, rather, concerted bodily action - gathering, gesturing, standing still, all of the component parts of "assembly" that are not quickly assimilated to verbal speech - can signify principles of freedom and equality (Butler, 2015, p. 48).

\section{Theatre and Health}

It is clear that in the society of efficient functioning, where the body has been separated from the forms-of-life, the myth of health at any cost suffers a setback because fear is not only the engine that causes the power to organise itself as a bio-power, but also a devastating and irrepressible consequence of the inevitable failures of an idea of care unable to take into account complexity in an adequate manner. One must think, in this regard, of the inequality of outcomes in traditional health treatments and cures, due to social, cultural, economic, political and other variables. One thinks, in this regard, of the inequalities that are created by a series of social, cultural, economic and political variables, the outcomes of which are controlled with increasing difficulty by traditional health treatments and care interventions ${ }^{50}$. The theatre, brought back to its origin of being a personal experience, is today watched with interest and sometimes included, all due allowances made, in treatment protocols (Rossi Ghiglione, 2011a). On the one hand the bio-power medicine is thus trying to harness and tame it, forcing it into rigid protocols; on the other hand, Social and Community Theatre ${ }^{51}$, training ground of our power of action, looks more and more as a movement of resistance capable of bringing out desire, a sure sign that alerts us to the possibility of acting in the situations of real life.

The theatrical experience is a body in performative relation with other bodies, it is a body that assumes, creates and transforms languages, it is free representation of oneself within a defined and recognised perimeter, it is a question about the sense of being and of being in a particular situation. Without considering this existential dimension of theatricality, one can never understand the reason that today pushes people of different social backgrounds, of different ages, of the most different origins to want to "make" theatre rather than to "go to" the theatre.

${ }^{50}$ For further information please refer to the forthcoming Proceedings of the International Study Day Teatro, salute e disuguaglianze, Turin, 1 February 2018, one of the projects issued from the PRIN Performing the Social. Education, Care and Social Inclusion through Theatre. ${ }^{51}$ For an explanation of the meaning of Social and Community Theatre see the Notes on Translations on p. 7. The expression is used in this sense throughout the paper. 
Bodies are able to produce transformation processes in public spaces through their mere presence and collective alliance. Social and community theatre activates forms of performativity, that is to say forms of coordinated action which are designed to serve as social practices of resistance:

So this movement or stillness, this parking of my body in the middle of another's action, is neither my act nor yours, but something that happens by virtue of the relation between us, arising from that relation, equivocating between the I and the we, seeking at once to preserve and disseminate the generative value of that equivocation, an active and deliberately sustained relation, a collaboration distinct from hallucinatory merging or confusion (Butler, 2015, p. 9).

The Social and Community Theatre is the model of a necessary theatre that cares. The necessity of the theatre is not unconnected with human corporeity, but it is a consequence of its statute: just as one cannot live without eating, there is no real quality of life without the mechanisms of representation which underlie cognitive, affective and relational processes - being nourished by experience.

Theatre is this sustenance, the place where one can rediscover oneself, one's own history, one's own dimension as a subject and one's role within the world one lives in. It is, in short, the possibility to act in the what if dimension, but also a direct performative action to achieve and maintain health, as this was defined in The Ottawa Charter for Health Promotion in November 1986:

Health is created and lived by people within the settings of their everyday life; where they learn, work, play and love. Health is created by caring for oneself and others, by being able to take decisions and have control over one's life circumstances (WHO, 1986). 